\title{
A Marriage Bar of Convenience? The BBC and Married Women's Work I923-1939
}

\begin{abstract}
In October 1932 the BBC introduced a marriage bar, stemming what had been an enlightened attitude towards married women employees. The policy was in line with the convention of the day; marriage bars were widespread in the inter-war years operating in occupations such as teaching and the civil service and in large companies such as Sainsbury's and ICI. However, once implemented, the BBC displayed an ambivalent attitude towards its marriage bar which had been constructed to allow those married women considered useful to the Corporation to remain on the staff. This article considers why, for its first ten years, the BBC bucked convention and openly employed married women and why, in 1932, it took the decision to introduce a marriage bar, albeit not a full bar, which was not abolished until 1944 . It contends that the $\mathrm{BBC}$ marriage bar represented a quest for conformity rather than active hostility towards the employment of married women and demonstrates how easily arguments against the acceptability of married women's work could be transgressed, if seen as beneficial to the employer. Overall, the article contemplates how far the BBC's marriage bar reflected inter-war ideology towards the employment of married women.
\end{abstract}

\section{Introduction}

In 1960, a contributor to the BBC's Woman's Hour programme described her young life in the 1920s. She reminisced:

There was little hope of combining marriage and career. Plenty of women were out of jobs, and many employers dismissed their female staff as soon as a wedding ring appeared. You were either a single woman doing (or looking for) a paid job, or a married woman running a home. ${ }^{1}$

Frances Gomm's recollections would have rung true with countless British women in the inter-war years: the expectation that once married you would become a housewife, your priority husband, family and home. It was an ideology reflected in women's magazines of the period as well as in the BBC's own broadcasts aimed at its female daytime audience. ${ }^{2}$ Yet, there was an awkward tension: the inter-war years were also a time of expanding employment opportunities for women not only in shops and offices and on the burgeoning assembly lines but also in the professions, assisted by the passing of the 1919 Sex Disqualification (Removal) Act, which opened up to women careers such as engineering, veterinary surgery and law. ${ }^{3}$ Despite the convention to leave work on marriage, many women wanted to retain their jobs and not only the trained and educated career-woman. The lure of new consumer goods and the quest for the ideal home meant that, for some, the benefits of a double-income were tempting, at least until children were born. ${ }^{4}$ For large numbers of women, however, the option to stay in work was unavailable; marriage bars compelled them to resign.

As a new industry, the BBC faced full-on the changing landscape of women's employment. ${ }^{5}$ Established in late 1922 as the British Broadcasting Company, its initial remit was to encourage the sale of wirelesses and to co-ordinate the new medium of radio in the UK. ${ }^{6}$ John Reith, originally General Manager, was retitled Director General on 1 January 1927 when the BBC was reconstituted as the British Broadcasting Corporation, its commitment to public service broadcasting enshrined by royal charter. At first, those who 
came to the BBC were truly pioneers, men and women prepared to accept the uncertainties of working for an emerging enterprise. Very quickly, a male-dominated hierarchy was imposed; a public school education and/or active wartime service being high amongst the prerequisites of Reith and his deputy Charles Carpendale in their selection of senior staff. ${ }^{7}$ But whilst the old school tie was important there was also an embracing of meritocracy, an 'office boy to Director General' ethos, with bright and able staff rising through the ranks. ${ }^{8}$ This applied to women as well as to men.

The BBC grew exponentially: from a staff of four in December 1922, by early 1932, when the Corporation decamped from rented premises at Savoy Hill to purpose-built Broadcasting House, women made up around 400 of the 1,300 established employees. At the outbreak of the Second World War, 1,362 women worked at the Corporation, almost a third of the total staff of $4,233 .{ }^{9}$ Women were employed by the BBC in three capacities: as hourlypaid charwomen, under the supervision of the (male) House Supervisor who also oversaw the weekly-waged waitresses, cloakroom and kitchen staff; as weekly waged clerical/secretarial staff under the supervision of the Women Staff Supervisor/Administrator (from 1931 this was Miss Freeman, who would be pivotal to the introduction of the BBC marriage bar) and as monthly-paid 'senior' staff in jobs as varied as drama producer, press officer, registry supervisor, orchestra secretary and furniture buyer. Figures from April 1936 reveal that out of the 875 female staff employed both regionally and in London, 193 were charwomen, 682 held catering/clerical/secretarial positions and sixty-two were salaried. ${ }^{10}$ Three BBC women, Hilda Matheson, Mary Somerville and Isa Benzie, attained 'Director' status in the inter-war years as, respectively, Director of Talks (1927 to 1932), Director of School Broadcasting (1931 to 1947) and Foreign Director (1933 to 1938). The BBC took an unusually progressive approach towards its female employees. Besides good pay and conditions of service, for weekly-waged staff there was the possibility of promotion to the salaried ranks. This reflected the BBC's recruitment policy of employing older office workers (few joined before the age of eighteen) who were either experienced or educated beyond the basic elementary grade. ${ }^{11}$ For the salaried, many of whom had been to university, there was an ostensible commitment to equal pay and equal promotional opportunities. Initially, there was also an acceptance of married women's work. This contrasts with, for example, teaching and the Civil Service, two occupations that absorbed large numbers of educated women in the inter-war years, where promotion prospects were inequitable and unequal pay and resignation on marriage legally enforced. ${ }^{12}$

By the early 1930s, the BBC had developed from a haphazard and experimental new venture into a highly centralised and professional institution, one that viewed itself as central to the promotion of moral, cultural and educational values in the UK. ${ }^{13}$ The rapid change from pioneering enterprise to established bureaucracy created a confusion of identity for the BBC which prided itself on being broad-minded and forward-looking yet wanted the trappings of convention and respectability. This article contends that the marriage bar, introduced in 1932, was a symbol of this conformity. ${ }^{14}$ The BBC marriage bar was never intended to be a blanket bar: it did not apply to those on contracts, so had no impact on female broadcasters, actors or musicians, while women on the established staff who were defined as 'exceptional' were eligible to remain. The notion of the 'exceptional woman' had developed from a perception within the BBC that married women employees fell into two distinct classes: those who proposed 'to remain in the ranks of women workers permanently' and those 'whose mind is not here but in their homes'. ${ }^{15}$ While the BBC might be pleased to lose the latter, it was keen to retain the former and between 1934 and 1937 it operated a Marriage Tribunal where this distinction could be discerned. Women who put forward a case 
for retention were judged on five criteria including loyalty, efficiency and indispensability along with career-mindedness and an ability to balance married life with office work. In addition, compassionate circumstances were considered, revealing the deep paternalism of the BBC. In the three-and-a-half years the Tribunal functioned, it heard the cases of twentynine individual women dismissing thirteen of them, all of whom were waged. However, as had been the case before the introduction of the bar, whether waged or salaried, most BBC women elected to resign on marriage indicating an acceptance of the cultural norm that a married woman's place was in the home.

This focus on the BBC marriage bar provides a fresh lens through which to view attitudes towards women, and in particular working women, in the 1920s and 1930s. Although marriage was the pre-text, the deliberations around the BBC bar expose deeply held sentiments towards social class, aptitude for work and the employer's responsibility for the welfare of employees. It also offers new insights into women's motivation for work and the notion of a career. The article is the first to consider in detail the application of a marriage bar in a large institution and draws extensively on documentation held at the BBC's Written Archives Centre. While the wider context of marriage bars in the inter-war years has been examined by historians such as Jane Lewis, Helen Jones and Gerry Holloway there have been, to date, few comprehensive studies of the circumstances surrounding married women's work in business or the professions. ${ }^{16}$ There are exceptions. Alison Oram revealed the devastating personal impact of marriage bars on women teachers which led to impassioned political campaigning amongst those who were unionised. ${ }^{17}$ This was paralleled in the Civil Service, as Helen Glew has shown in her investigation into the marriage bar in the GPO. ${ }^{18}$ Here, as with teachers, the marriage bar forced a choice between matrimony and a career. Judy Faraday's study of women managers in the John Lewis Partnership provides an intriguing counterpoint. John Spedan Lewis, the founder of the Partnership in 1928, positively promoted the recruitment of married women managers, particularly in the early days, believing them to be more loyal and to better understand the needs of customers. ${ }^{19}$ Unlike the John Lewis Partnership, the BBC was not pro-active in its recruitment of married women but neither did it dismiss out-of-hand married women's work. Rather, as will be shown, the BBC took a largely pragmatic stance. How to approach the married women question would remain a subject of internal debate throughout the 1930s.

\section{The Marriage Bar in the Inter-War Years}

The origins of inter-war attitudes towards married women's work lie in the late nineteenth century when middle-class women first entered the workforce. As Jane Lewis, Elizabeth Roberts and others have shown, arguments about whether working-class married women should work were already pervasive, based on economic considerations, for example the primacy of the male breadwinner and social considerations such as a woman's duty of care to her husband and child. ${ }^{20}$ In 1876, the Post Office introduced the first formal marriage bar in the UK. With educated women newly recruited to the service, there was concern that continuity of employment would be compromised by motherhood. ${ }^{21}$ By the outbreak of the First World War, marriage bars had become commonplace in occupations such as the civil service and banking and, to some extent, in teaching. Edith Morley, Professor of English Language at Reading University was certain they were loathed by many women. In her 1914 book, Women Workers in Seven Professions, she observed:

'Wherever the subject of the employment of married women is mentioned... there is adverse comment on the economically unsound, unjust and racially dangerous 
tendency in many salaried professions to enforce upon women resignation on marriage'. 22

The issues highlighted by Morley: the waste of highly educated, well-trained and experienced workers; the unfairness of celibacy being a condition of female employment and fears that professional women would choose a career over child-bearing, so affecting the calibre of the race, continued to be pertinent in the 1920s and 1930s. Crucially, Morley identified the nub of frustration with the marriage bar; that its impact was most profound on the well-educated and professional. Throughout the inter-war years there was a tacit acceptance that, for many working-class married women, to continue earning was a necessity and casual labour, homeworking, taking in lodgers and so on, were routine. Charwomen, for instance, were almost always married. ${ }^{23}$

Although many marriage bars were relaxed or lifted during the First World War by the early 1920s these were not only reinstated but were more widespread. This was partly for economic reasons; the 'Geddes Axe' of 1922, with its severe cuts to local authority budgets, prompted the sacking of married women employees, especially teachers, through the imposition of bars. ${ }^{24}$ The Sex Disqualification (Removal) Act, 1919, despite its clear statement that, 'a person shall not be disqualified by sex or marriage... from assuming or carrying on any civil profession or vocation' was circumvented by the Civil Service, which successfully negotiated exemption, nor did it apply to the Church, armed forces or Stock Exchange. ${ }^{25}$ In addition, when tested in law, it became apparent that while the Act might enable married women to work, it did not entitle them to do so. ${ }^{26}$ A Private Member's Bill that sought protection for married women workers failed in 1927 and there were no further attempts to challenge marriage bars in parliament during the inter-war years. ${ }^{27}$ This lack of parliamentary success did not mean the right of married women to work was not vigorously defended. In 1928, activists pressurised Manchester City Council to rescind its marriage bar and similar success was achieved with the London County Council in 1935. Women's organisations such as the Six Point Group, the Open Door Council, the Women's Freedom League and the St Joan's Political and Social Alliance all supported the right of married women to work. In 1934 they joined together with a host of women's trade unions and other interest groups to lead the Campaign for the Right of the Married Woman to Earn. ${ }^{28}$

Feminist campaigners may have been vociferous in their agitation against the marriage bar, but theirs was a minority voice. As has been indicated, it was custom, not enforcement, which led most women to leave paid employment when they married. That a husband should provide for his family remained a widely held belief. Neither was it viewed as practicable for a respectable woman to attempt both to work and run a home. When the press got a whiff of the BBC's marriage bar in August 1933, the Glasgow Evening Citizen bellowed:

How can a woman possibly do justice to her home and to her family if she has to devote her attention to another job? Equally, how can she fulfil her obligation to her employer if her mind is preoccupied, as it must be, with domestic affairs? ${ }^{29}$

If social attitudes placed wives and mothers in the home, the economic climate of the interwar years also militated against married women in the workplace. During the Depression, anger was directed at married women workers who were seen to be taking jobs from single women as well as unemployed men. Even the socialist and feminist Margaret Cole 
acknowledged the 'very real fear' among men if married women were encouraged to earn, a fear shared by their wives. ${ }^{30}$

While many middle-class women, with their training and career aspirations, were opposed to marriage bars others were positive about them. Those who had chosen a career over marriage might see in their application less competition for rare promotional opportunities. ${ }^{31}$ Resignation on marriage could also prompt a marriage gratuity, something of particular importance to the less well-off. When, in January 1930, nearly 7,000 lower grade female clerks in the Civil Service were asked if they favoured the abolition of the marriage bar, if it meant the end of the marriage gratuity, only 138 women voted in favour. This caused the feminist writer Winifred Holtby to remark:

Who are the girls who voted for the marriage bar? Nine out of ten swing daily to their offices in suburban trains and trams and buses, carrying in their suitcases a powderpuff and a love-story or Home Chat.... They think that if only they could marry all would be well. ${ }^{32}$

This 'meanwhile attitude' of young women, filling in time before they married, was bemoaned by feminists, in particular the employment campaigner Ray Strachey, and was seen as one of the stumbling blocks to women's professional advancement. ${ }^{33}$ Writing in the Manchester Guardian Vera Brittain also lamented the belief that 'business' was the chief concern of men but 'personal relationships' the main interest of women, with marriage the 'be-all and end-all' of her existence. ${ }^{34}$ This, Brittain believed, translated into the theory that when women entered work it was only a 'meantime' occupation between school and marriage that needed to be 'neither carefully studied nor adequately paid'.

Marriage had a fundamental effect on women's experience of work and the perception of women's work in the inter-war years. As highlighted by Brittain, the belief that married women would leave the workforce gave little incentive for training. As early as 1920, the political activist Barbara Drake had highlighted the damaging impact this had on female apprenticeships, coining the phrase 'mortality by marriage' ${ }^{35}$ It also had a detrimental effect on women's pay. As Samuel Cohn has argued and Helen Glew has verified, the high-turnover of female staff in the GPO was seen as economically advantageous because it ensured a constant flow of fresh and cheap new recruits. ${ }^{36}$ Another worry raised by forcing working women to shun matrimony was the possibility of a secret marriage or, worse still, compelling a couple to 'live in sin'. Speaking at the Mass Meeting for the Right of the Married Woman to Earn in 1933, Nancy Astor declared that, because of marriage bars, 'thousands of women nowadays are secretly married, or, worse still, living with the men they ought to be married to'. ${ }^{37}$ There were certainly cases of women teachers and assembly-line workers who concealed their wedding rings to keep their marriages hidden. ${ }^{38}$ In fact secret marriages were so commonplace that, according to Ray Strachey, insurance companies offered special arrangements whereby married women employees continued transactions in their maiden names. $^{39}$ Three cases of secret marriage were identified at the BBC, the women subsequently dismissed. $^{40}$

Marriage bars were not universal. Those with creative careers were largely immune which, in part, may explain the BBC's initial progressive attitude. As Ray Strachey noted, when it came to the arts, 'women musicians, painters, actresses and writers may marry as much as they please, and do in fact marry without abandoning their careers. ${ }^{41}$ For some factory workers, there was also a tradition of married women's work, for example in the 
Lancashire textile mills. ${ }^{42}$ Neither did all businesses eschew married women; EMI, GEC and Hoover did not operate bars. ${ }^{43}$ John Spedan Lewis made clear that, at the John Lewis

Partnership, if a married woman was the best candidate, she would get the job. ${ }^{44}$ The London School of Economics also took a positive approach towards the employment of married women to the extent that its Director, William Beveridge, introduced a system of child benefit for staff in $1925 .{ }^{45}$ Women academics, unlike schoolteachers, were rarely subject to marriage bars. A 1933 survey by the British Federation of University Women estimated that there were at least 100 married women working in British universities. ${ }^{46}$ An exception was Liverpool University which, in 1933, introduced a bar; the case of Dr Margaret Miller, who was forced to resign, sparked the Campaign for the Right of the Married Woman to Earn. ${ }^{47}$

The issue of married women's work was patently contentious during the inter-war years. The BBC initially chose to abide by the principle that married women had equal status; they were not debarred from applying for posts neither were they compelled to resign but by 1931, this attitude had begun to change. Documentation on the employment of married women at the BBC has been retained making it possible to explore, for the first time, how and why an inter-war marriage bar was introduced.

\section{The BBC Marriage Bar}

In 1928 Valentine Goldsmith, the Assistant Controller with responsibility for Administration clarified, in a letter to John Reith, the BBC's position with regard to the employment of married women. 'The principle of women working with equal status is accepted. The principle of married women so working is also accepted. ${ }^{48}$ Prior to 1928 , no official document states that married women were eligible to work at the BBC, it was accepted practice, nor is there any clear rationale as to why the BBC adopted the custom. As an innovative post-war Company undergoing fast and haphazard growth, questions as to a woman's marital status appear not to have been a recruitment priority; decisions were made instead on aptitude and whether an individual was likely to be an asset to the BBC. In 1932, an audit of married female staff showed that out of an approximate female staff of 400, both in London and the Regions, thirty-one married women were employed by the Corporation in jobs as varied as talks assistant, Multigraph operator, telephonist, matron, registry clerk, shorthand typist and secretary. ${ }^{49}$

Although married women were entitled to work at the BBC there was an informal practise of resignation on marriage, as illustrated by the staff magazines which celebrated weddings and engagements. For example, in May 1928, The Saveloy (the original staff newsletter) informed its readers that Isabel Shields, Reith's personal secretary, had left to be married. Of the eight other women whose matrimony was announced only two had elected to stay with the Corporation. The approaching marriage and retirement of Miss Johnson, secretary to the Manchester Station Director, was described as a 'disaster looming ahead' implying that management were often frustrated that marriage led to resignation. ${ }^{50}$ Certainly Reith recorded his sadness that Miss Shields had gone, noting in his diary her loyal and devoted service over five 'very strenuous' years. ${ }^{51}$

In late 1928, the BBC was confronted by one of the realities of employing married women staff: maternity. Mary Somerville, the de facto Head of School Broadcasting, had recently married and in November announced her pregnancy causing Reith to comment, 'talked about Miss Somerville who is going to have a baby and wants to stay at work'. ${ }^{52}$ Somerville's desire to retain her job prompted the BBC to clarify its position on maternity leave; there was no precedent within the Corporation because it was rare for a woman to be pregnant while at 
work. Indeed, details about paid maternity provision in Britain at this time are hard to find, probably because it was so unusual. Even the progressive John Lewis partnership only offered extended unpaid leave, with an allowance for financial hardship. ${ }^{53}$ In a letter to Reith about the Somerville issue, the head of administration, Goldsmith, was clear that, because the BBC accepted the employment of married women, 'it is not only against public policy it is also illogical to rule that motherhood entails dismissal'. ${ }^{54}$ With this principle established, he suggested a scheme of four months on full pay and up to a further four months on half pay. ${ }^{55}$ In his closing sentence to Reith, Goldsmith indicated that he was aware of the modernity of his proposal, 'I feel that any large corporation or commercial organization should take this risk rather than assume a nineteenth century attitude in the present circumstances of women's employment'. ${ }^{56}$ The BBC's view of itself as pioneering in its attitude towards Somerville and maternity is further illustrated in a letter from Hilda Matheson to Vita Sackville-West in May 1929. Somerville, now on maternity leave, had become seriously ill and there was concern about the baby. Matheson wrote, "It will be sad if all the plans for making her a spectacular vindication of the success of keeping on your job and baby don't come off - poor Maisie."57 The BBC accordingly situated itself as an enlightened institution, in contrast to long-standing professions such as the Civil Service and banking where attitudes towards married women staff were negative and entrenched.

There is no single explanation as to why this forward-looking attitude began to change; the reasons appear to be partly economic, partly societal, partly personal and partly to do with the BBC's changing perception of itself. By 1931, the Depression had taken a deep hold in the UK and, with millions out of work, discussions about married women's employment were heightened. This was true at the BBC where economic considerations were coupled with new perceptions about women's motivation for work, as will be discussed. In addition, the Corporation had become a highly regarded national institution with senior management increasingly confident of their place within the establishment. The largest interwar rise in licence holders was recorded in 1931, with listener numbers now estimated at 16 million. ${ }^{58}$ Politicians, business leaders and the cultural elite now flocked to Savoy Hill, a development largely credited to Hilda Matheson who, in 1927, had become the BBC's first Director of Talks. ${ }^{59}$ As Matheson wrote in 1933, broadcasting was becoming 'a part of national and international machinery'. ${ }^{60}$ With marriage bars part of the prevailing cultural orthodoxy in Britain, a BBC marriage bar might accordingly add to the Corporation's sense of conformity and respectability. It is probably no coincidence that the introduction of the bar coincided with the move from the ramshackle offices of Savoy Hill to the grandeur of Broadcasting House in 1932.

The first inklings of an alteration in attitude towards the BBC's married women came in early 1931 when there was a 'tentative' discussion on the Employment of Married Women at Control Board, Reith's weekly meeting of top management. ${ }^{61}$ In September 1931, in light of rising unemployment, the focus was on whether women whose husbands were in work should be refused BBC posts while at a December meeting, the discussion moved to the treatment of women staff who married in the future and to whether they should be allowed to remain. $^{62}$ It was decided that Douglas Clarke, Goldsmith's assistant in the Administrative department, would investigate practices in other firms. In September 1932, Clarke reported to Goldsmith that he had held discussions with the London Life Association, the Ministry of Labour, ICI, Prudential Assurance, the National Provincial Bank, the LCC, Marconi and the Underground Railways of London. ${ }^{63} \mathrm{He}$ had also sought corroboration from the Civil Service. With the exception of the Underground Railways of London, Clarke testified, all terminated the contracts of women staff on marriage giving as their reasons 'principally the 
labour market' but also expressing the view that married women, 'could not well carry on a business and run a home'.

Clarke's analysis of the pros and cons of employing married women, as detailed in his report to Goldsmith, is revealing. ${ }^{64}$ On the pro-side, he acquiesced, women had the right to 'live as they think fit' and so choose to remain in employment after marriage. Such women, Clarke assessed, would obtain an experience and balance lacking in certain single women; they would also be more stable staff members, 'as they will not have the restless outlook of so many girls who are contemplating marriage'. On the counter-side, with the labour market in its present condition, Clarke ascertained, it was unfair for married women who were supported by their husbands to compete against unmarried women, who needed to earn. In addition, it would seem 'impossible' for a married woman both to work and maintain a reasonable home for her husband and family, 'it would seem that either her work in business must suffer, or her health, or her husband, or her children'. It might also mean she would not have children, 'which might be bad for the community and herself'. He concluded that the arguments against retention outweighed those for retention although, he concurred, it was 'a most difficult matter to decide upon'. Douglas Clarke's musings thus reflected many of the pervading viewpoints on married women's work in the inter-war years.

Economic concerns had already become significant to the BBC. 1932 witnessed the UK's highest unemployment figures, with the number of individuals out of work nearing three million. ${ }^{65}$ By May 1932, the Corporation was working to the principle that vacancies should be filled by unmarried women or widows, rather than married women whose husbands were in employment. ${ }^{66}$ In August 1932, Clarke confirmed that, in view of the existing state of unemployment, women were, 'discouraged as far as possible from remaining with us after their marriage'. ${ }^{67}$ Looking back (from the vantage point of 1938) to the circumstances leading up to the marriage bar Miss Freeman, the Women's Staff Administrator, recalled that, 'any decisions we reached in regard to the retention or otherwise of married women on the staff was largely governed by the economic and social conditions existing at that time. ${ }^{68}$ Certainly, from 1929, there had been calls nationally for married women's work to be restricted. The Anomalies Act of 1931, for example, debarred married women from unemployment benefit unless they could prove intent to return to work. ${ }^{69}$ However, although economic considerations certainly informed the Corporation's initial discussion on married women's work, documents from 1932 show that this was not the prime reason for the introduction of the bar. More exactly, it was a perceived difference in attitude displayed by married women towards their work that became the overriding rationale.

In August 1932, a series of emotive memos from the BBC's administrators, Clarke and Goldsmith, underlined a change in outlook towards married female staff. The catalyst was a reconsideration of the BBC's system of Marriage Leave. This was a concessionary week's leave, supposedly for the honeymoon, granted to both male and female employees. Clarke, the first to raise the issue, was angered by what he saw as an abuse of the system whereby some women took Marriage Leave even though they intended to resign. These 'girls', he declared, wished to remain with the BBC only for a short period, in order to add to their means, and so were, 'making a convenience of the Corporation and in certain cases causing inconvenience to us'. ${ }^{70}$ Clarke informed Goldsmith that, with Miss Freeman's agreement, the extra week's leave should no longer be given to such women. Frustration was focussed upon one woman, Miss R., whose work with the BBC had not been in 'anyway noteworthy' and he and Freeman would be, 'rather glad to replace her'. 
Clarke's memo raised two apposite points: women's intention to stay at the BBC after marriage and their aptitude. It begged the question: should those considered to be inadequate in their work have the right to stay? Goldsmith's response is telling. He both supported Clarke and Freeman's desire to tighten up Marriage Leave and elaborated on Clarke's distinction between women's motivation for work:

The first [class of woman are] those who intend to marry and remain in the ranks of women workers permanently ... i.e. they regard themselves equally with their husbands, as workers, and not as domestic partners in the marriage..... The second class consists of those who have no intention of being women workers save for their financial needs during a temporary period of getting a home together, whose outlook is different and whose mind is not here but in their homes. ${ }^{71}$

Although not specifically referring to social class, Goldsmith's comments echo what interwar feminists identified as the 'meanwhile' attitude of many young women to their work. Ray Strachey in particular lamented the prevalence of this perspective amongst those in the lower paid ranks of 'business', including clerical workers, shorthand typists and telephonists, where women were eager to swap the routine of their jobs for the idealised notion of the "nice little home'. ${ }^{72}$ At the BBC, it was this 'class of woman' that Goldsmith wanted to discourage, those whose commitment to the Corporation was not complete. As he reasoned, Miss Freeman would have refused Miss R's continuation of service had she been free to do so but, 'our marriage rules bereft her of this freedom' ${ }^{73}$ That the introduction of the BBC marriage bar was ignited by this particular incident is confirmed by Freeman who recalled that, '[it] was, as far as I recollect, the case that made me first query the Corporation's policy with regard to the automatic retention of women staff after marriage'. ${ }^{74}$ Indeed, when the specifics of the bar were promulgated to women staff it was made clear that 'certain cases' had led the BBC to reconsider its position. ${ }^{75}$

Although by the autumn of 1932 the BBC was preparing to introduce a bar, it was mindful of how its standing as a progressive organisation might be affected. As Goldsmith indicated, the 'DG' (Reith) wanted to discourage married women workers but the BBC had hesitated to change the rule because, 'in women's papers our outlook has been upheld as a good one facing modern facts, and any change would have immediate outside notice and be widely commented upon' ${ }^{76}$ In fact, a few days before the Board of Governors met to approve the marriage bar there was worrying news for the BBC; feminist campaigners appeared to have learnt of the Corporation's plans for change. On 21 October, Mary Somerville, now Director of School Broadcasting, informed Clarke that the 'Suffragette element' of the women's organisations (presumably the Campaign for the Right of the Married Woman to Earn) were seeking a test case on the grounds that it was illegal to force a woman to resign on marriage. ${ }^{77}$ Should the Corporation come to a decision that women should either be dismissed or required to resign, Somerville thought it likely the test case would be the BBC although, as mentioned above, it turned out to be Liverpool University.

Despite concerns about how a marriage bar might be externally perceived, on 27 October 1932 the BBC Board of Governors approved its introduction. ${ }^{78}$ It was agreed that married women would no longer be recruited by the BBC and that, in future, only 'exceptional' women who married would be retained although no married woman already on the staff would be required to resign. Fearful, however, of bad publicity, the BBC were cautious about how the change should be announced to the outside world and any press that got an intimation of the Corporation's plans were to be told there was no truth in the report 
that married women's services were to be terminated. ${ }^{79}$ Technically this was true; there was no intention to remove women who were already married. One of the ways the Corporation avoided scrutiny was by not incorporating the new ruling into the Staff Agreement or the Standing Instructions, so there was no 'official' policy change, just an adaptation of practice. ${ }^{80}$

It took nine months to finalise the wording of the 'Statement to Women Staff' which was delivered not by Valentine Goldsmith but by Basil Nicolls who, in a Corporation restructuring, had replaced him as the re-designated Director of Internal Administration. ${ }^{81}$ On 15 August 1933, the BBC's female employees were informed that, while there was to be no definite bar, in future the retention of married women was to be regarded as exceptional and dependent upon the circumstances of individual cases. In coming to this decision, the statement continued, the Corporation had:

...largely been guided by a belief that only an exceptional woman, with adequate material resources, can perform her duties satisfactorily as a whole-time servant of the Corporation, while attempting to fulfil the cares and responsibilities of a young family. ${ }^{82}$

A class element to the bar was immediately apparent. Firstly, management were quick to point out that only women with sufficient finances could consider the possibility of both work and home. Secondly, the BBC's charwomen were to be exempt as were female lavatory and cloakroom attendants. This was because women of the type employed in these posts were 'traditionally married'. ${ }^{83}$

Unfortunately for the BBC, its 'Statement to Women Staff' was leaked to the press. ${ }^{84}$ The story was carried by the London Evening News, the Daily Mail and the Glasgow Evening Citizen, amongst others. ${ }^{85}$ The most damning report was in the Daily Mirror which included both a full-page article and an editorial. Under the headline 'BBC Dictatorship: Married Women's Rights', the barrister and political activist Helena Normanton railed as to whether, 'some policy of more or less compulsory celibacy' was on its way. 'Fair play is such a jewel', she protested, 'that it would make us all very uneasy to feel that there is any possibility of one rule... for the highly-placed woman, and another and harsher for the stenographer or translator. ${ }^{86}$ Normanton was right in her assertion that the highly-placed BBC woman would be safe from the bar; the Corporation made no secret of the fact that exceptions to the rule would mainly occur amongst the senior staff. But the stenographer and translator, if viewed as 'exceptional', might also be given leave to remain. The thorny task for BBC management was how to determine which women should be exempt from the bar, a problem initially solved by the introduction of the Marriage Tribunal at the close of 1933 .

\section{The BBC Marriage Tribunal}

It seems probable that the Marriage Tribunal was inspired in part by a procedure that existed within the Civil Service. The Royal Commission on the Civil Service, which reported in 1931, had drawn attention to the marriage bar. It identified a variance in attitude towards the higher and lower grades of civil service women; 'a considerable body of opinion' being in favour of treating the higher grades differently. ${ }^{87}$ It was therefore decreed that exceptional women could be retained on marriage if it was judged in the public interest, individual cases going before the Treasury. ${ }^{88}$ The BBC Governor Mary Agnes Hamilton had been a member of the Royal Commission so would have been aware of this ruling. ${ }^{89}$ According to the new Director of Internal Administration, Basil Nicolls, it was Hamilton who mooted the idea of 
the BBC Marriage Tribunal. ${ }^{90}$ In this she was supported by Mary Somerville who, as the most senior female member of staff, was involved in the early deliberations on the BBC bar. Notwithstanding her own position as a married woman and mother, Somerville appears to have agreed with the viewpoint that only exceptional women should be eligible for retention after marriage, of which she was undoubtedly one, her case being used by Nicolls as an illustration of this point. ${ }^{91}$

The modern working wife was not an unknown quantity in the inter-war years, a figure both celebrated and vilified in women's magazines. ${ }^{92}$ As Ray Strachey had pointed out, actresses, artists, musicians and writers were often wives and mothers (as Strachey herself was) and married women were not debarred from being lawyers, General Practitioners or politicians. ${ }^{93}$ These were, by definition, 'exceptional' women. Mary Somerville herself often featured in the press; an admiring Radio Pictorial article from 1935 revealed how she balanced her frantic BBC day with evening bath-time for her young son, though not without significant help from a housekeeper. ${ }^{94}$ Intriguingly, the Corporation's two highest paid women were both married. In 1939, Mary Somerville earned $£ 1500$ per annum; her colleague Mary Adams, a senior Talks Producer, earned £900. Both women negotiated the concession to 'network' in their own homes, an essential component of their jobs, for which they were eligible to claim expenses. ${ }^{95}$ This reveals an understanding on the part of BBC management that, as wives and mothers (Adams had a daughter in 1936), their lives had added complexity. The Foreign Director, Isa Benzie, on the other hand, chose to resign her $£ 900$ position on marriage in 1938, 'clear in her mind' that she did not want to 'lead the double life that some girls do' ${ }^{96}$ Although there is no evidence that other married women who remained on the staff gained the privileges of Somerville and Adams, regardless of rank, all retained the same opportunities for pay increases and promotions as unmarried female staff. ${ }^{97}$

In May 1933, Mary Somerville attended a meeting where the substance of the BBC Marriage Tribunal was discussed. ${ }^{98}$ Here it was decided that any woman henceforth planning to marry and 'desiring to know whether she would be regarded as an exceptional case', would have her circumstances considered by a small tribunal made up of three senior administrative executives, (usually Basil Nicolls, Douglas Clarke and Miss Freeman) and two impartial members of the senior staff, one male and one female. Cases would be judged on a points system, under five criteria:

1) Special value of experience, making replacement difficult or undesirable. (Maximum 100 points)

2) Compassionate circumstances. (Maximum 50 points)

3) Long service and general efficiency. (Maximum 50 points)

4) Character as bearing on the strain of combining married life with office work. (Maximum 50 points)

5) Intention of making a career in the BBC. (Maximum 50 points) ${ }^{99}$

The documentation of the Marriage Tribunal, which met for the first time on 28 December 1933, makes engrossing reading, both the minutes of the hearings themselves and the behind-the-scenes discussions. There were no set times for the Tribunals rather they were convened as applications arose, sometimes two or three cases being heard at a sitting. The woman concerned was not herself present instead documents were submitted from her managers and from Miss Freeman, who spoke to each individual beforehand to garner the particular details of her situation. (Freeman discouraged those with potentially hopeless cases from applying.) ${ }^{100}$ The information provided to the Tribunal could be highly personal, with 
emotive descriptions of the woman's personality and qualities. The scrutiny given to the minutiae of their lives is unsettling; it is hard to imagine the personal life of a male employee being probed in the same way. At the opening of each Tribunal, the Chairman read a statement warning members that they were called to 'interpret a policy and that they should not be guided by their personal views on the policy itself', which suggests awareness that not all BBC senior staff were supporters of the bar.

In the three-and-a-half years it functioned, the Tribunal heard the cases of twenty-nine women (three of them twice) and dismissed thirteen of them. All five salaried women who applied were successful in their bid to remain as were eleven waged women including three secretaries, two high-grade shorthand-typists and four clerks. But looking through the minutes, one is instantly struck by the arbitrary nature of the scoring system; of those retained a waged Clerk and Women's Staff Supervisor in Cardiff was marked highest (271/300), while a salaried Assistant in Music Routine gained the lowest score (203/300), largely a consequence of the subjectivity of the material under consideration. ${ }^{101}$ Members of the Tribunal were notably impressed by longevity; of the ten women with less than four-and-ahalf years' service only one was kept on, Mary Allan, who had been appointed specifically to run the Television Make-up and Wardrobe Department. ${ }^{102}$ Similarly, all those awarded their Ten-Year Bonus, whether salaried or waged, received unanimous votes for retention indicating the importance of loyalty for the BBC. Fifteen women pronounced their intention of remaining with the Corporation even if their husbands had sufficient finances to support them, only two of whom were subsequently required to resign. Thus commitment to a career with the BBC was demonstrably viewed in a positive light.

Criterion Four exposed a myth. That a woman could not successfully combine married life with office work was a view widely held by those who supported marriage bars, yet here was the BBC admitting the contrary. Only three of the women who came before the Tribunal were viewed as temperamentally unsuited to the task. Of the remaining twenty six, the intention to employ domestic help, the fact of being physically robust, and the potential lessening of the domestic burden, were all regarded as eminently plausible reasons of how and why a married woman could effectively manage work and home. ${ }^{103}$ Although the issue of childbearing was not discussed, the BBC's policy on maternity leave assumed that this would not extend beyond two children. ${ }^{104}$ The 'Statement to Women Staff' made clear that maternity provision, (agreed at three months on full-pay) would be on the strict understanding that, should the woman concerned suffer ill health or become inefficient, the Corporation could terminate her services. ${ }^{105}$

The criterion that caused the most soul-searching for the Tribunal was 'Compassionate Grounds'. Nearly all the women provided evidence that their prospective husbands were not earning enough 'to keep two people in any degree of comfort' ${ }^{106}$ One was a ballet dancer whose income was subject to perpetual fluctuations; another, an osteopath in a new practice; a third an architect earning $£ 3$ a week, 'with prospects of a slow increase'. ${ }^{107}$ For many women, and their fiancés, there were financial dependents: an elderly father, widowed mothers, younger siblings who were students or in precarious jobs. One applicant was, 'suffering from a disease which did not at present affect her efficiency, but was such that her doctor had strongly urged her to get married as the best method of affecting a cure', for which she scored $43 / 50$ points. ${ }^{108}$ What this disease was is unknown, and was not revealed to the Tribunal, but the medical urgency was taken seriously. 
Did 'Compassionate Grounds' extend to enforced celibacy? The imposition of spinsterhood was one of the most forceful arguments used against the marriage bar in the inter-war years, particularly by those campaigning for its abolition in teaching and the Civil Service, and a memorandum from March 1935 shows the BBC grappling with the issue. Two women failed at the Marriage Tribunal in 1934. Both chose to remain on the staff rather than marry and the following year reapplied, the financial circumstances of their prospective husbands having worsened. In his weighing up of their second appearance, the Director of Internal Administration, Nicolls, was clear that under the ruling as laid down by the Governors, they should not be kept on. However, he acknowledged that, 'Here we are up against the very difficult policy question of our action preventing early marriages'. For Nicolls the central question was, 'are we better served in the long run by Miss X or Miss Y as an embittered, because compulsory, spinster, or by her as a contented married woman allowed to remain on the staff? ${ }^{109}$ It was agreed both women could stay.

Aside from the Marriage Tribunal, other taxing issues relating to married women had to be faced. For example, one of the supposedly clear principles of the BBC bar was that married women would no longer be recruited by the Corporation yet despite this, a number were subsequently employed. In the summer of 1933 Reith personally sanctioned the return of Mrs Caroline Towler who, as Caroline Banks, was Miss Freeman's predecessor. A great favourite of Reith's, she had resigned on marriage in 1931 but when her naval officer husband became unemployed she appealed to her former boss to be allowed back. ${ }^{110}$ Now a mother of two young children, including a four-month old baby, Mrs Towler was offered the position of Night Hostess, a salaried job that involved meeting and greeting the evening's broadcasters. As with Mary Somerville, the press were intrigued by the novelty of a high-profile working mother; an article in the London Evening News assured its readers that her children would not be missing her much 'for her duties do not start until 6.30pm'. ${ }^{111}$ This praise of working mothers reveals the ambivalence of the press towards married woman's work, on the one hand revering it, on the other treating it as an abomination. This inconsistency was also apparent in conflicting attitudes towards spinsterhood, particularly within teaching. By the mid-1930s, the Times Educational Supplement was reflecting arguments that children should be taught by women who had the widest experience rather than twisted, unnatural, unmarried women, a point of view voraciously put forward by teachers campaigning against the marriage bar. ${ }^{112}$ In November 1936, in the light of this reasoning, the BBC marriage bar was relaxed to allow married women to apply for jobs as Children's Hour Organisers and for salaried work in the School Broadcasting Department, both sections of the BBC where a married woman's understanding of the needs of children was perceived to be beneficial. ${ }^{113}$

Whether the BBC's temporary female staff should be covered by the marriage bar was another area of ambiguity, particularly as the UK's employment situation improved and the demand for skilled women workers grew, especially in London. Many occupations and industries which imposed marriage bars made exceptions for casual labour such as holiday cover or seasonal work. ${ }^{114}$ In similar circumstances the BBC used agency staff, those who had previously worked for the Corporation being viewed as particularly valuable. That these were invariably married women was confirmed by Miss Redfern, the General Office Supervisor, who explained how shortages in the labour market meant, 'unmarried girls ... are snapped up immediately for permanencies'. ${ }^{115}$ From early 1937, however, BBC supervisors found themselves increasingly in conflict with the Administration Division over their use of temporary married women staff, especially for lengthy contracts. To ensure the marriage bar was not being breached by the back door, it was agreed in June 1937 that married women from agencies could be employed for a maximum of six-months at a time but for no more 
than eight months in any given year, a practical solution that reflected the reality of the market-place. $^{116}$

Alongside these concerns, the Marriage Tribunal continued but in July 1937 it was suspended having not been judged a success. ${ }^{117}$ Undoubtedly, the BBC's reluctance to lose loyal, conscientious and valued staff played a large part in its perceived failure. Of the thirteen women who failed at the Tribunal, only five were unanimously dismissed and only one of these because of her perceived inadequacy. During its lifetime, the application of the criteria had been relaxed revealing a palpable distaste amongst the Corporation's administrators towards forcing women to resign. On a more practical note, the Tribunal was viewed as work intensive for $\mathrm{BBC}$ management, it put the women who chose to have their cases heard under immense strain and it was inefficient. ${ }^{118}$ As the Deputy Director General, Charles Carpendale observed difficulties were, 'inherent in any procedure where compassionate circumstances and considerations other than the intrinsic needs of the service are admitted as grounds for making an exception to a general rule'. ${ }^{119}$ With the Marriage Tribunal deemed unworkable, how should the BBC now approach its bar?

\section{The Abolition of the BBC Marriage Bar}

For Miss Freeman the way forward was unequivocal; although initially supportive of the marriage bar and Tribunal, by March 1937 she had changed her mind. She informed William St John Pym, the new Director of Staff Administration (who had replaced Basil Nicolls in the summer of 1936), that she would now, 'welcome an experiment on the other side, namely the definite lifting of the bar'. ${ }^{120}$ Freeman gave two reasons for her revised standpoint: the shortage of good secretarial workers and because it was the only subject on which there was, 'a justifiable feeling of discontent among the women staff', although this was never manifest in organised protest. (For instance, a meeting organised by the Association of Women Clerks and Secretaries to rally support amongst BBC staff against the bar was only attended by a handful of women. $)^{121}$ In early November 1937, in a further memo to Pym, Freeman reiterated that, following discussions with her opposite numbers in various organisations both in the UK and in America, she had come to believe that the abolition of the bar 'would seem to me more in line with the Corporation's policy regarding all other women staff matters' ${ }^{122}$ Pym was also now of the view that the bar should be abolished, commenting 'that it probably does more harm than good'. ${ }^{123}$ A former Chief Inspector of Schools for the London County Council, Pym's views may have been influenced by the raising of the LCC bar for teachers in 1935. ${ }^{124}$

However, the views of Freeman and Pym were to be ignored. In June 1937, Mary Agnes Hamilton, coming to the end of her term as a BBC governor, suggested the Corporation might be better served if it operated its bar on similar lines to the Civil Service i.e. only women above a certain grade or salary could be considered for retention. ${ }^{125}$ This was supported by Carpendale, who proposed a scheme whereby the marriage bar would be absolute for all women staff below Salary Grade ' $C$ ' i.e. those earning less than $£ 400 \mathrm{a}$ year. ${ }^{126}$ On 16 November 1937, Carpendale’s proposal came before the Board of Governors. Hamilton, although she had initiated the new scheme, was one of two governors who voted against the retention of the bar but, outnumbered, the motion was carried. ${ }^{127}$ The following day, women staff were informed that, with the agreement of the Board of Governors, it had been decided to abolish the Tribunal and tighten the bar, bringing the Corporation's practice, 'into conformity with that of the Civil Service. ${ }^{, 128}$ Thus the BBC changed its marriage bar ostensibly to one stripped of all criteria for retention other than the needs of the Corporation. 
Although the BBC marriage bar was tightened, there is ample evidence that it continued to be flouted. During 1938, the eight-month rule introduced for temporary staff was waived for married women telephonists who were considered essential to the new telephone enquiry service, as Miss Freeman emphasized, there were 'no good unmarried telephonists out of jobs'. ${ }^{129}$ A similar argument was put forward by the Catering Manager who, in an impassioned flurry of memos, decried the lack of suitable waitresses; as a result married women waitresses became eligible for work at the BBC. ${ }^{130}$ This was later extended to all women catering staff. ${ }^{131}$ It was also agreed that married women wardrobe assistants could be employed in television as this was 'customary'. ${ }^{132}$ In October 1938, Pym suggested to Thomas Lochhead (the newly appointed Controller, Administration) that there should be a less rigid interpretation of the marriage bar rule and the re-introduction of an element of compassion for women currently on the BBC staff. Pym also re-emphasised that the 'right policy' was the removal of the bar, and he had new ammunition. ${ }^{133}$ Attached to his memo was a report from Ray Strachey. In the summer of 1938 Miss Freeman had contacted Mrs Strachey, in her capacity as Secretary of the Women's Employment Federation, requesting information about marriage bars in the UK. ${ }^{134}$ The subject was 'exceedingly tangled', replied Strachey, and 'every kind of variety of practice can be found'. She then went on to list occupations that did and did not require women to resign, ending with an expression of her own belief that 'the only just solution is to keep all employments open. Leave the women themselves to decide which to do'. Although Strachey's letter failed to convince Lochhead, it shows that both Freeman and Pym were attuned to the wider debate on marriage bars.

John Reith left the BBC in June 1938 to take up a new post at Imperial Airways. His replacement as Director General, Frederick Ogilvie, while not seeing the marriage bar as a priority was prepared to reconsider the issue. It is possible that his previous role as an academic, (he had been Vice-Chancellor of Queen's University Belfast), made him more amenable to change and he intimated that he would consider a review, but not until October 1939. ${ }^{135}$ But by then the Second World War had begun. At the end of August 1939, with war imminent, Miss Freeman sought urgent clarification on the situation for women who decided to marry. ${ }^{136}$ Pym responded that the marriage bar would be relaxed but only for women in Categories A and B, i.e. those women who continued to work for the Corporation; it remained in force for woman in Category C, i.e. those seconded to areas of work outside the BBC. ${ }^{137}$ On 2 October 1939 the new ruling was promulgated to women staff who were informed that, should they marry during the war, they would be required to resign at the ending of hostilities. ${ }^{138}$ In April 1940, it was reported that 43 women clerical staff had since married; the main issues the BBC now faced being whether a married secretary could work in the same office as her husband (it was not allowed) and whether their staff details should be altered to reflect their married name (only if the woman herself requested this). ${ }^{139}$ The wartime removal of the BBC bar was in line with most occupations including the Civil Service and teaching. Under the National Service Act of December 1941, single women aged 20-30 were conscripted, however married women were strongly encouraged to work albeit with exemptions for mothers of infants and school-aged children. ${ }^{140}$

In September 1941 Miss Freeman was redeployed as Staff Welfare Officer. ${ }^{141}$ Her replacement was Gladys Burlton, an acknowledged staffing expert who, in the mid-1920s, had established the highly successful Burtlon Staff Agency and the Burlton Institute. ${ }^{142}$ Once in post, Burlton soon questioned the differing treatment for women in Category' C'. Although only twenty-four women were affected, she could discern 'no possible reason' for the continuing discrimination. ${ }^{143}$ In February 1942, the wider issue of the BBC marriage bar 
was raised; Burlton's modernity apparent in the phrase, 'I do not believe we should bind ourselves to reverting after the war to this surprising old Corporation policy'. ${ }^{144}$ Spurred on by the Assistant Director of Staff Administration, A.C. Cameron, Burlton prepared a report for the new Director General, Robert Foot. ${ }^{145}$ (Ogilvie had resigned in January 1942, his replacement a diarchy of Robert Foot and Cecil Graves). Her impassioned six-page critique of the Corporation's marriage bar was submitted on 17 April $1942 .{ }^{146}$

Burlton identified two major contradictions of the bar: firstly that it functioned despite many aspects of it being disliked by managers and secondly its regressive nature in an institution that held enlightened attitudes towards staff. Exposing the paucity of theories behind marriage bars, she in turn took to task the domestic argument, the financial argument and the efficiency argument producing a stark indictment of BBC policy. In considering the domestic argument, she contested whether any employer, however wise, was better fitted to decide the question of whether any individual woman should stay than the woman herself. The assumption seemed to be 'that a girl who has always proved herself a level-headed, capable person, fit to hold a responsible position, loses all her sense immediately she marries and becomes incapable of judging how to conduct her life.' The financial argument was dismissed thus: 'The principle behind this argument is that no-one should be allowed to work who does not 'need" to do so.... It follows that no-one (man or woman) with sufficient private means should be allowed to follow a profession'. As to the efficiency argument, Burtlon declared: 'The idea that married women are as a class less efficient than unmarried women is demonstrably untrue'. She concluded with an emotional flourish, worthy of feminist writers such as Holtby and Brittain:

Why should we class marriage with misdemeanour, inefficiency, ill health and old age as a reason for dismissing a woman from her employment? Why should a married woman who has devoted the whole of her single life to mastering a profession be debarred from continuing to practise it? This is surely a grave infringement of the rights of women in a democratic country. ${ }^{147}$

Gladys Burlton's fervid words had immediate effect. Two weeks later, on 29 April 1942, Foot agreed to rescind the ruling governing women in Category C. ${ }^{148}$ It was also agreed that the question of married women's employment would be reviewed once hostilities were over. ${ }^{149}$ But while Burlton may have exposed the futility of marriage bar ideology, it was economic reality that appears ultimately to have led to the ending of the bar. In November 1943, Foot expressed the view that after the war, bars imposed by individual employers were no longer likely to be effective as married women so terminated would simply seek work elsewhere. His inclination was, therefore, that following the ending of hostilities, the BBC bar should be removed. ${ }^{150}$ In the event, the decision came earlier; on 21 September 1944, the Board of Governors agreed that the marriage bar should not be re-imposed after the war, though this would be reconsidered if, at any time, the continued employment of married women appeared to the Corporation to be against public policy. ${ }^{151}$ Following this decree, there is no further mention of 'Married Women Policy' within the BBC. Economic imperatives also saw the lifting of the marriage bar in teaching (1944) and the Civil Service (1946), where staffing shortages also made it expedient to continue the employment of married women. ${ }^{152}$

\section{Conclusion}

Gladys Burlton's analysis of the inefficiencies and contradictions of the BBC marriage bar revealed what had long been the Corporation's unease with its policy: it was 
never convinced that married women should not work. Whereas the inter-war narrative of the marriage bar in professions such as teaching and the Civil Service was predominantly that of women's battle to overturn it, at the BBC it was the story of the Corporation's justification in applying it. The difficulty for BBC administrators was their empathy with married women's appetite for work, both for financial reasons and for the fulfilment of a career. By retaining married women staff the BBC accepted that it was possible to 'serve two masters'; to both care for a husband and family and remain a productive member of staff. This is important because it countered directly the widely held maxim that a woman's place was in the home. However, the identification within the BBC of two distinct classes of married women, those who wanted a career and those whose 'heart was in the home', was in many ways a truism. In line with the convention of the day, the majority of the Corporation's female staff left voluntarily when they wed. For the few who came before the Marriage Tribunal, there was a palpable sense of discomfort amongst managers that they should be passing judgement on an individual's decisions about work and domestic life, a sentiment that was not shared by the impersonal and monolithic Civil Service. Even though this was the model to which the BBC marriage bar would ultimately aspire, the 'intrinsic needs' of the Corporation continued to include married women whose work was seen as vital to the smooth running of the organisation.

Whereas established professions such as the Civil Service and teaching displayed long-held and deeply entrenched prejudice towards women, the young BBC prided itself on being enlightened in its approach to female staff. The marriage bar, however, exposed a major inconsistency; because it was discriminatory it was out of line with the Corporation's ostensible policy of equality in terms of women employees. The tension lay in the reasons for its introduction: the BBC saw in its marriage bar a quick fix response both to the economic climate and to the issue of 'inconvenient' girls. In none of the discussions leading up to start of the bar was inequality an issue. Rather, the bar was seen as a natural development; if they were operated by prominent institutions such as ICI, Prudential Assurance, the LCC and Marconi then surely it made sense for the BBC also to adopt the practice. By doing so, they were conforming to a convention that was accepted by most professions and industries. However, while on the one hand there was confidence that, in terms of the establishment, the $\mathrm{BBC}$ would be seen to be doing the right thing, on the other hand there was awareness that public opinion might view the introduction of a bar differently.

By the early 1930s, the BBC was already positioning itself as the voice of the nation, gratified by its burgeoning social, moral and cultural role. But with this prominence came acute scrutiny, not only from politicians and the press but from the general public. Concerned about how the introduction of the bar might be portrayed in the print media and worried about potential feminist agitation, the BBC did all it could to avoid the headlines. It was fortunate for the Corporation that it did not fall in the spotlight of the Campaign for the Right of the Married Woman to Earn. The concerted action and bad publicity directed at Liverpool University caused it to rescind its marriage bar. Very possibly for the BBC, the fact that it was the lower ranks who were predominantly affected by the bar rather than higher grade professional staff, kept its marriage policy away from the eyes of the mainly middle-class activists. Nor was there any organised protest within the BBC against the marriage bar, a situation very different from that of the Civil Service and teaching where women-only trade unions campaigned vigorously against it.

This focus on the BBC and its rich archival documentation has offered new insight into attitudes towards married women's work in the inter-war years. It shows BBC managers' 
interpretation of marriage bar ideology and how they continually wrestled with the pros and cons of employing married women, displaying ambivalence about both their recruitment and the implications of forcing them to resign. In the case of the BBC, the slowness to end its marriage bar appears to be due far more to the bureaucratic nature of the Corporation itself rather than to a fundamental belief that its 'Married Women's Policy' was right.

\footnotetext{
1 'Cold Comfort or Common-sense?' a talk by Frances Gomm, Woman's Hour, 30 May1960. BBC Written Archives Centre, Caversham, (WAC): Woman's Hour scripts.

${ }^{2}$ See for example Fiona Hackney, "'They Opened Up a Whole New World": Feminism, Modernity and the Feminine Imagination in Women's Magazines, 1919-1930', PhD thesis, University of London, 2011, 137-180; Maggie Andrews, Domesticating the Airwaves: Broadcasting, Domesticity and Femininity, (London, 2012), 181.
}

${ }^{3}$ See for example Deirdre Bedoe, Back to Home and Duty: Women between the Wars 1918-1939(London, 1989); Selina Todd, Young Women, Work and the Family in England 1918-1950 (Oxford, 2005); Leonore Davidoff and Belinda Westover(eds), Our Work, Our Lives, Our Words: Women's History and Women's Work (London, 1986); Miriam Glucksmann, Women Assemble: Women Workers and the New Industries in Inter-War Britain (London, 1990); Krista Cowman and Louise Jackson (eds), Women and Work Culture in Britain c18501950 (Aldershot, 2005).

${ }^{4}$ For a discussion on new consumerism and the ideal home see for example Deborah S Ryan, The Ideal Home through the $20^{\text {th }}$ Century (London, 1997), 33-86.

${ }^{5}$ See Catherine Murphy, “'On an Equal Footing with Men?” Women and Work at the BBC, 1923-1939', PhD thesis, University of London, 2011.

${ }^{6}$ For a detailed history of the foundation of the BBC see Asa Briggs, The Birth of Broadcasting, The History of Broadcasting in the United Kingdom Vol. 1 (London, 1961) 94-142.

${ }^{7}$ This is immediately apparent in the memoirs of e.g. Richard Lambert, Ariel and All His Quality (London, 1940); Maurice Gorham, Sound and Fury (London, 1948); Lionel Fielden, The Natural Bent (London, 1960).

${ }^{8}$ WAC: L1/15/1: Doris Arnold Staff file, Gielgud to Eckersley, comment by Carpendale, 1 Sep1930.

${ }^{9}$ The 1939 figures come from the Establishment Chart for 1 Jul 1939, WAC: R/49/178/16: Staff Policy:

Establishment. The 1932 figures have been approximated from a breakdown of staffing for 1934, using the first available Staff List. The ratio of female to male staff was generally around one third.

${ }^{10}$ WAC: R49/187: Staff Policy: Establishment Quarterly Returns, 1 Apr 1936.

${ }^{11}$ Elementary schooleducation ended at fourteen, which remained the school-leaving age until 1947.

12 See Alis on Oram, Women Teachers and Feminist Politics 1900-1939 (Manchester, 1996).

${ }^{13}$ See David Hendy, Public Service Broadcasting (Basingstoke, 2013).

${ }^{14}$ This article draws on Chapter Three of my PhD thesis. Murphy, 'On an Equal Footing with Men', 129-183.

${ }^{15}$ This article draws extensively on three files relating to the BBC's Married Women's Policy (MWP), R49/371/1-3. MWP:1, 1928-1935, Goldsmith to Carpendale(?), 26 Aug 1932.

${ }^{16}$ Jane Lewis, Women in England 1870-1950: Sexual Divisions and Social Change (Brighton, 1984); Helen Jones, Women in British Public Life 1914-50 (Harlow, 2000); Gerry Holloway, Women and Work in Britain since 1840 (London, 2005).

17 Oram, Women Teachers.

${ }^{18}$ Glew, 'Women's Employment in the GPO'. Meta Zimmeck also included information about the marriage bar in her study of women civil servants in the inter-war years. Meta Zimmeck, 'Strategies and Stratagems for the Employment of Women in the British Civil Service 1919-1939’, Historical Journal 27.4 (1984), 903-904, 922923.

${ }^{19}$ Judy Faraday, 'A Kind of Superior Hobby: Women Managers in the John Lewis Partnership 1918-1950’, MPhil. thesis, University of Wolverhampton, 2009.

${ }^{20}$ Lewis, Women in England, 45, 49-50; Elizabeth Roberts, Women's Work 1840-1940 (Cambridge, 1988), 1416. See also Sheila Lewenhak, Women and Trade Unions: An Outline History of Women in the British Trade Union Movement (London, 1977), 41, 94.

${ }^{21}$ For a discussion on the introduction of the marriage bar in the GPO see Glew, 'Women's Employment in the GPO', 119-122.

${ }^{22}$ Edith Morley, Women Workers in Seven Profession (London, 1914), xv.

23 The census for 1921 showed 8.8\% of married women were in employment; for 1931 the figure was $9.7 \%$. Jane Lewis records the census figures for married women differently, at $14 \%$ in 1911, 14\% in 1921 and $16 \%$ in 1931. Lewis, Women in England, 152. 
${ }^{24}$ Oram, Women Teachers, 26.

${ }^{25}$ Sex Disqualification (Removal) Act, 1919, 9\&10, Geo.5. Ch. 71. See also Mari Takayanagi, 'Parliament and Women, c.1900-1945', PhD thesis, University of London, 2012, 54-67; Glew, 'Women’s Employment in the GPO', 125-126.

${ }^{26}$ For example, in 1925, a challenge to the bar was brought by a female teacher in Dorset. When the case of Short v Poole Corporation went to appeal, the Corporation, who won, maintained that, 'the duty of married women was primarily to look after her [sic]domestic concerns, and they regarded it as impossible for her to do so and to act effectively and satisfactorily as a teacher at the same time'. Erna Reiss 'Changes in the Law', in Ray Strachey (ed.), Our Freedom and Its Results (London, 1936), 99.

27 Sir Robert Newman's Private Member's Bill was sponsored by the National Union of Societies for Equal Citizenship. For a detailed analysis of the introduction of the Bill see Olive Banks, The Politics of British Feminism, 1918-1970 (Aldershot, 1993), 55.

${ }^{28}$ See Jennifer Bhatt, 'Margaret Miller and the Campaign for the Right of the Married Woman to Earn', MPhil thesis, University of Leicester, 1995.

${ }^{29}$ Glasgow Evening Citizen, 31 Aug 1933.

${ }^{30}$ Margaret Cole, Marriage: Past and Present (London, 1938), 202.

31 Jones, Women in British Public Life, 155.

32 Manchester Guardian, 31 Jan 1930. From Paul Berry and Alan Bishop (eds), Testament of a Generation: The Journalism of Vera Brittain and Winifred Holtby (London, 1985), 65.

${ }^{33}$ Ray Strachey, Careers and Openings for Women: A Survey of Women's Employment and a Guide for Those Seeking Work (London, 1935), 52-54.

${ }^{34}$ Vera Brittain, Manchester Guardian, 27 Sep1928. From Berry and Bishop, Testament of a Generation, 125126.

${ }^{35}$ Barbara Drake, Women in Trade Unions (London, 1920), 190, 232.

${ }^{36}$ Samuel Cohn, The Process of Occupational Sex-Typing. The Feminisation of Clerical Labour in Great Britain (Philadelphia, 1985) 94-105; Glew, ‘Women’s Employment in the GPO', 127. Selina Todd also concurs that marriage bars were economically motivated. Selina Todd, 'Young Women, Employment and the Family in Inter-war England', PhD thesis, University of Sussex, 2003, 51.

${ }^{37}$ Daily Mail, 15 Nov1933.

38 Oram, Women Teachers, 56; Glucksmann, Women Assemble, 223.

${ }^{39}$ Strachey, Careers and Openings for Women, 60.

${ }^{40}$ MWP:2, Freeman to Pym, 7 Oct 1938.

${ }^{41}$ Strachey, Careers and Openings for Women, 61.

${ }^{42}$ Lewis, Women in England, 149.

${ }^{43}$ Glucksmann, Women Assemble, 117, 140.

${ }^{44}$ The Gazette, 27 Jul 1929.

${ }^{45}$ William Beveridge, The London School of Economics and Its Problems 1919-1937 (London, 1960), 46.

${ }^{46}$ University of Liverpool: Margaret Miller Papers: P822/1.

${ }^{47}$ Bhatt, 'Margaret Miller'. See also Carol Dyhouse, No Distinction of Sex? Women in British Universities 1870-1939 (London, 1995), 163-68.

${ }^{48}$ MWP:1, Goldsmith to Reith, 27 Nov 1928.

49 MWP:1, 25 Oct 1932: Brief Report on Married Women at Present Working for the Corporation. .

50 The Saveloy, May 1928.

${ }^{51}$ WAC: S60/5/2/2 Reith Dairies, 29 Feb 1928.

${ }^{52}$ Reith Diaries, 22 Nov 1928.

${ }^{53}$ Faraday, 'A Kind of Superior Hobby', 83.

${ }^{54}$ MWP:1, Goldsmith to Reith, 27 Nov 1928.

${ }^{55}$ In this, he appears to have been guided by the pre-marriage bar custom of the London County Council which, according to a hand-written note, operated a systemof eight weeks full/nine weeks half pay .WAC: L2/195/1

Mary Somerville Personal File, Carpendale to Goldsmith, 7(?) Dec 1928.

${ }^{56}$ MWP:1, Goldsmith to Reith, 27 Nov 1928.

${ }^{57}$ Mathes on to Sackville-West, 14 May 1929.

${ }^{58}$ Mark Pegg, Broadcasting and Society, 1918-1939(London 1983), 7.

${ }^{59}$ For a discussion on Matheson's role in the BBC see Michael Carney, Stoker: The Biography of Hilda Matheson O.B.E., 1888-1940 (Llangynog, 1999), 23-84.

${ }^{60}$ Hilda Mathes on, Broadcasting (London, 1933), 207.

${ }^{61}$ WAC: R3/3/7: Control Board Minutes, 5 Feb 1931. The Control Board was the decision making body of the BBC comprising Reith, his Deputy Carpendale and a changing number of Controllers.

${ }^{62}$ Control Board Minutes, 22 Sep 1931, 15 Dec 1931. 
${ }^{63}$ MWP:1, Clarke to Goldsmith, 23 Sep 1932.

${ }^{64}$ Same document.

${ }^{65}$ W.R Garside, British Unemployment 1919-1939: A Study in Public Policy (Cambridge, 1990), 5.

${ }^{66}$ MWP:1, Goldsmith to Regional Directors, 16 May1932.

${ }^{67}$ MWP:1, Clarke to Goldsmith, 16 Aug 1932.

${ }^{68}$ MWP:1, undated and unsigned memo. Judging by its content and personal nature, I have no doubt that it was written by Miss Freeman. It is placed with documents from 1938.

${ }^{69}$ Pamela M. Graves, Labour Women: Women in British Working Class Politics, 1918-1939 (Cambridge, 1994), 188.

${ }^{70}$ MWP:1, Clarke to Goldsmith, 16 Aug 1932.

${ }^{71}$ MWP:1, Goldsmith to Carpendale? 26 Aug 1932. It is not clear who this was addressed to.

72 Strachey, Careers and Openings for Women, 57.

${ }^{73}$ Same document.

${ }^{74}$ MWP:1: Freeman, undated and unsigned memo.

${ }^{75}$ MWP:1, BBC Marriage Bar Statement, 15 Aug 1933.

${ }^{76}$ MWP:1, Goldsmith to Carpendale? 26 Aug 1932.

${ }^{77}$ MWP:1, Clarke to Goldsmith, 21 Oct 1932.

${ }^{78}$ WAC: R/1/1: Board of Governors Minutes, 27 Oct 1932.

${ }^{79}$ MWP:1, Miss Cockerton to Freeman, 3 Nov 1932.

${ }^{80}$ MWP:1, Clarke to Goldsmith, 21 Oct 1932.

${ }^{81}$ MWP:1, Statement to Women Staff, 15 Aug 1933.

82 Same document.

${ }^{83}$ MWP:2, 26 Jan 1938, unattributed hand-written note at foot of memo.

${ }^{84}$ MWP:1 Nicolls to Reith, 30 Aug 1933. Despite strenuous efforts to discover the source, the individual was never identified.

${ }^{85}$ Evening News, 28 Aug 1933; Daily Mail, 29 Aug 1933; Glasgow Evening Citizen, 31Aug 1933.

${ }^{86}$ Daily Mirror, 28 Aug 1933.

${ }^{87}$ Glew, 'Women’s Employment in the GPO', 127.

${ }^{88}$ Between 1934 and 1938, eight women in the Administrative Grades were retained on marriage, this out of an estimated female staff of 77,000. Hilda Martindale, Women Servants of the State,1870-1938 (London, 1938), 156.

${ }^{89}$ Mary Agnes Hamilton, Remembering My Good Friends (London, 1944), 264.

${ }^{90}$ MWP:1, undated memo from early 1934, signed Nicolls.

91 “The case of Miss Somerville may be quoted as an illustration, although she was married long before the forming of the rule. If her case were to come up afresh now it would almost certainly be held that her special experience in schoolbroadcasting was of great value and made her very difficult to replace.” MWP:1, undated memo from early 1934, signed Nicolls.

92 Hackney, 'Women's Magazines', 182.

93 Strachey, Careers and Openings for Women, 61.

${ }^{94}$ Radio Pictorial, Oct 1935.

${ }^{95}$ See for example WAC: S322/39/2: Mary Adams Correspondence:Talks Department: Expenses.

${ }^{96}$ WAC:L1/1049/: Isa Benzie Staff File, 27 Jun 1937, from ? to Nicolls

${ }^{97}$ See Salary Information Files, WAC: R62/100/1-3.

${ }^{98}$ MWP:1, undated memo Somerville to Nicolls, c12 May 1933.

${ }^{99}$ WAC: R49/372: Married Women’s Policy Tribunals (MWPT), Tribunal Minutes, 30 Jan 1934, and all subsequent tribunals.

${ }^{100}$ See e.g. MWP:2, Freeman to Nicolls, 14 Jul 1936; Nicolls to Pym, 21 Jan 1937.

101 Tribunals, 9 Jul 1936, 3 May 1937.

102 Tribunal, 17 Feb 1937.

103 See for example Tribunals, 16 Oct 1936, 11 May 1936, 19 Jan 1937.

${ }^{104}$ MWP:1, Goldsmith to Reith, 27 Nov 1928.

${ }^{105}$ MWP:1, Statement to Women Staff, 15 Aug 1933.

106 Tribunal, 17 Jul 1937.

107 Tribunals, 17 Jul 1937, 5 May 1935, 11 May 1936.

108 Tribunal, 17 Jul 1934.

${ }^{109}$ MWPT, 6 Mar 1935, Nicolls to Carpendale. For a discussion on the embittered spinster see Katherine Holden, The Shadow of Marriage. Singleness in England, 1914-1960 (Manchester, 2007), 15-16.

${ }^{110}$ Reith Diaries, 9 Jun 1933.

${ }^{111}$ Evening News, 26 Aug 1933. 
${ }^{112}$ Times Educational Supplement, 20 Jul 1935, quoted in Oram, Women Teachers, 186.

${ }_{113}^{113}$ MWP:2, Clarke to Freeman, 3 Nov 1936.

${ }^{114}$ Married teachers were often considered acceptable for supply work and the GPO also employed married women as temporary staff during busy times, Oram, Women Teachers, 69-70; Glew, 'Women's Employment in the GPO', 161-163.

${ }^{115}$ MWP:2, Clarke to Freeman, 8 Feb 1937.

${ }^{116}$ MWP:2, Extract from Mrs Winship’s file, 4 Jun 1937.

${ }^{117}$ The final case was heard on 16 Jul 1937.

${ }^{118}$ During the period the Tribunal was functioning, 79 women had chosen voluntarily to resign on marriage.

MWP:2, Staff Records to Clarke, 16 Jul 1937.

${ }^{119}$ WAC: R3/3/12: Control Board Minutes, 25 Oct 1937, Note on Proposed Marriage Bar.

${ }^{120}$ MWP:2, Freeman to Pym, 9 Mar 1937.

${ }^{121}$ R49/857: Staff Policy Trade Unions: AWCS 1936-1938, Freeman to Pym, December $17^{\text {th }} 1937$.

${ }^{122}$ MWP:2, Freeman to Pym, 2 Nov 1937.

${ }^{123}$ Same memo, hand-written note by Pym.

${ }^{124}$ The minutes of the feminist campaigning groups the Open Door Council and the Six Point Group, showhow they worked with the National Union of Women Teachers to pressurise the council to end the bar. The Women's Library: Six Point Group: 5SPG/B/01-5, AGM’S and Annual Reports 1931-1935; Open Door Council:

5ODC/A/05, Annual Reports.

${ }^{125}$ MWP:2, Carpendale to Pym, 30 Jun 1937.

${ }^{126}$ MWP:2: Note on Proposed Marriage Bar, 25 Oct1937. Grades A, B and C were the top three salary grades.

${ }^{127}$ WAC: R1/5/1/ Board of Governor's Minutes 1936-1937, 10 Nov 1937. Sir Ian Fraser also wanted the rule abolished. HAL Fisher, Dr JJ Mallon and CHG Millis were in favour of retaining only senior women. The views of the other two governors (Viscountess Bridgman and RC Norman) were not recorded.

${ }^{128}$ MWP:2, Pym to All Women Staff, 17 Nov 1937.

${ }^{129}$ MWP:2, Freeman to Clarke, 27 Apr 1938.

${ }^{130}$ MWP:2, Clarke to Wade, 12 Oct 1938.

${ }^{131}$ MWP:2, Pym to Wade, 2 Nov 1938.

${ }^{132}$ MWP:2, Pym to Clarke, 2 Mar 1938.

${ }^{133}$ MWP:2, Pym to Lochhead, 3 Oct 1938.

${ }^{134}$ MWP:2, Strachey to Freeman, 20 Jul 1938.

${ }^{135}$ MWP:2, Graves to Lochhead, 12 Oct 1938.

${ }^{136}$ MWP:3, Women's Executive to Freeman, 25 Aug 1939.

${ }^{137}$ MWP:3, Pym to Freeman, 30 Aug 1939.

${ }^{138}$ MWP:3, Pym to all Women on the Permanent and Auxiliary Staff: Wartime Staff Administration: Instruction No. 8:Employment of Married Women, 2 Oct 1939.

${ }^{139}$ MWP:3 General Business Manager, 1 Apr 1940; Pym to Freeman and Clarke, 13 Jun 1941; Assistant

Director of Staff Administration to Assistant Head of Staff Records, 1 Jan 1942.

${ }^{140}$ Gail Braybon and Penny Summerfield, Out of the Cage: Women's Experiences of Two World Wars (London, 1987), 157-160.

${ }^{141}$ Miss Freeman's card index file shows she resigned on 30 Apr 1943, aged forty- two. In brackets under her name is written 'Mrs Ivin' indicating that she had married.

${ }^{142}$ Burlton had also written many books including Retail Selling (London, 1927) and Staff Service and Training (Manchester, 1935).

${ }_{143}$ MWP:3, Read (Assistant Women’s Establishment Officer) to Burlton, 19 Jan 1942.

${ }^{144}$ MWP:3, Burlton to Cameron, (Deputy Director of Staff Administration),12 Feb 1942.

${ }^{145}$ MWP:3, Cameron to Burlton, 27 Mar 1942.

${ }^{146}$ MWP:3, Burlton to Cameron, 17Apr 1942.

${ }^{147}$ Same document.

${ }^{148}$ MWP:3, Pym to Burlton, 29 Apr 1942.

${ }^{149}$ MWP:3, Beadle to Foot, 28 Apr 1942.

${ }^{150}$ MWP:3, Pym to Ashbridge, 12 Sep1944.

${ }^{151}$ MWP:3, Clerk to the Board to Pym, 22 Sep 1944.

${ }^{152}$ Harold L. Smith (ed.), War and social change: British society in the Second World War (Manchester, 1986), 219-12. 